\title{
Inverse association between serum creatinine and mortality in acute kidney injury
}

\author{
Associação inversa entre creatinina sérica e mortalidade na lesão \\ renal aguda
}

\section{Autores}

Sergio Pinto de Souza ${ }^{1}$

Rodrigo Santos Matos ${ }^{1}$

Luisa Leite Barros ${ }^{1}$

Paulo Novis Rocha ${ }^{1}$

${ }^{1}$ Federal University of Bahia.

Data de submissão: 17/01/2014. Data de aprovação: 29/08/2014

\section{Correspondência para:} Paulo Novis Rocha.

Faculdade de Medicina da Bahia da Universidade Federal da Bahia Departamento de Medicina. Av. Reitor Miguel Calmon, s/no, Vale do Canela. Salvador, BA, Brasil. CEP: 40110-100. E-mail: paulonrocha@ufba.br Fundação ABM de Pesquisa e Extensão na Área da Saúde (FABAMED); Coordenação de Aperfeiçoamento de Pessoal de Nível Superior (CAPES).

DOI: 10.5935/0101-2800.20140067

\section{Abstract}

Introduction: Sepsis is a leading precipitant of Acute Kidney Injury (AKI) in intensive care unit (ICU) patients, and is associated with a high mortality rate. Objective: We aimed to evaluate the risk factors for dialysis and mortality in a cohort of AKI patients of predominantly septic etiology. Methods: Adult patients from an ICU for whom nephrology consultation was requested were included. End-stage chronic renal failure and kidney transplant patients were excluded. Results: 114 patients were followed. Most had sepsis (84\%), AKIN stage $3(69 \%)$ and oliguria $(62 \%)$ at first consultation. Dialysis was performed in $66 \%$ and overall mortality was $70 \%$. Median serum creatinine in survivors and non-survivors was $3.95 \mathrm{mg} / \mathrm{dl}$ $(2.63-5.28)$ and $2.75 \mathrm{mg} / \mathrm{dl}(1.81$ 3.69), respectively. In the multivariable models, oliguria and serum urea were positively associated with dialysis; otherwise, a lower serum creatinine at first consultation was independently associated with higher mortality. Conclusion: In a cohort of septic AKI, oliguria and serum urea were the main indications for dialysis. We also described an inverse association between serum creatinine and mortality. Potential explanations for this finding include: delay in diagnosis, fluid overload with hemodilution of serum creatinine or poor nutritional status. This finding may also help to explain the low discriminative power of general severity scores - that assign higher risks to higher creatinine levels - in septic AKI patients.

Keywords: acute kidney injury; creatinine; intensive care units; mortality; renal dialysis; risk factors.

\section{Resumo}

Introdução: A sepse é considerada importante causa de Lesão Renal Aguda (LRA) em pacientes internados em Unidade de Terapia Intensiva (UTI), sendo esta síndrome associada à elevada mortalidade. Objetivo: Avaliar os fatores de risco para diálise e mortalidade em uma coorte de pacientes com LRA de etiologia predominantemente séptica. Métodos: Pacientes adultos com LRA internados em UTI avaliados pela equipe da nefrologia, sendo excluídos portadores de doença renal crônica terminal e transplantados renais. Resultados: 114 pacientes foram incluídos. A maioria apresentou sepse (84\%), estágio AKIN 3 (69\%) e oligúria $(69 \%)$ na primeira consulta nefrológica. Diálise foi realizada em $66 \%$; a mortalidade geral foi de $70 \%$. A creatinina mediana nos sobreviventes e não sobreviventes foi 3,95 $\mathrm{mg} / \mathrm{dl}(2,63-5,28)$ and 2,75 mg/dl (1,81 3,69 ). Nos modelos multivariáveis, oligúria e a ureia sérica foram positivamente associadas com diálise; entretanto, menor creatinina sérica na primeira consulta foi independentemente associada com maior mortalidade. Conclusão: Nesta coorte de pacientes com LRA de etiologia predominantemente séptica, oligúria e a ureia sérica foram as principais indicações de diálise. Também observamos associação inversa entre a creatinina sérica e mortalidade. Possíveis justificativas para esse achado são avaliação nefrológica tardia, sobrecarga volêmica com hemodiluição da creatinina sérica ou desnutrição. Este achado pode, ainda, ajudar a explicar o baixo poder discriminativo dos escores gerais de gravidade, que atribuem maior pontuação a valores maiores de creatinina, em pacientes críticos com LRA.

Palavras-chave: creatinina; diálise renal; lesão renal aguda; mortalidade; risco; unidades de terapia intensiva. 


\section{INTRODUCTION}

Acute kidney injury (AKI) is a frequent and often fatal complication of critical illness., ${ }^{1,2}$ The causes of AKI in this setting are diverse but sepsis and septic shock are by far the most common etiologies. ${ }^{3}$ Despite enormous advances in our ability to care for the critically ill that occurred over the last decades, especially in the area of renal replacement therapy (RRT), the mortality of septic patients with AKI remains unacceptably high, reaching up to $80 \%$ in some studies. ${ }^{4-6}$ There is substantial evidence from clinical studies that AKI adversely influences both short and long-term outcomes in ICU patients. ${ }^{7}$ The risk factors for short-term mortality in these patients include older age, need for dialysis, and extra-renal organ failure. ${ }^{8}$ Interestingly, some studies have found an inverse association between serum creatinine and mortality in unselected AKI patients., ${ }^{3,9-11}$

The diagnosis of AKI by AKIN and RIFLE criteria rests mainly upon the detection of changes in serum creatinine, ${ }^{12,13}$ with higher values resulting in higher stages. Some authors have suggested that higher AKIN stages are associated with worse clinical outcomes. ${ }^{13,14}$ From these observations, it could be derived that higher serum creatinine levels would be associated with increased mortality. However, the opposite was observed in a multicenter cohort of unselected AKI patients, ${ }^{2}$ where lower serum creatinine levels were found to be associated with higher mortality. Indeed, serum creatinine is a known marker of nutritional status, and lower values have been linked to mortality in maintenance hemodialysis patients. ${ }^{15}$ Nevertheless, the relationship between serum creatinine and mortality in septic AKI remains controversial. Herein, we investigated the role of creatinine levels as a predictor of mortality in a population of critically ill patients with established AKI of mainly septic etiology.

\section{Methods}

\section{STUDY POPULATION}

We included all AKI patients who underwent nephrology consultation in the ICU of a public hospital in Salvador-Bahia, Brazil, for a sixteenmonth period. The hospital's ICU is a 32-bed clinical and surgical unit. Chronic kidney disease stage 5, diagnosed according current guidelines, ${ }^{16}$ and kidney transplant patients were excluded.

\section{DATA COLLECTION AND DEFINITIONS}

This is a prospective observational cohort study. Standard physiological and laboratorial data were recorded on a daily basis. AKI was defined and staged according to the Acute Kidney Injury Network (AKIN), utilizing creatinine criteria. ${ }^{17}$ Sepsis was diagnosed in accordance with current guidelines, ${ }^{18}$ and septic etiology of AKI defined if sepsis preceded $\mathrm{AKI}$ and was considered its major precipitant. Oliguria was arbitrarily defined as a urinary output less than $400 \mathrm{ml}$ per day. Highest serum lactate, lowest serum bicarbonate and norepinephrine use (at least an 1-hour continuous infusion) were recorded; initial serum creatinine, septic AKI, and initial $\mathrm{PO}_{2} / \mathrm{FIO}_{2}$ ratio were categorized at the first nephrology consult day. Lactate and $\mathrm{PO}_{2}$ were obtained from arterial blood gas analysis (Radiometer ABL 520 Blood Gas analyzer ${ }^{\circledR}$, Radiometer, Copenhagen); "peak lactate" was the highest serum lactate level recorded throughout the ICU stay. Inspired oxygen fraction were recorded from ventilator settings or calculated from oxygen flow in non-invasive devices. Recovery of renal function was defined as dialysis independence at ICU discharge with a stable serum creatinine level lower than $50 \%$ of the maximum serum creatinine level.

\section{Patient management}

Dialysis treatment was instituted and individualized at the discretion of the attending nephrologist. The timing of initiation of RRT as well as the dose and mode of dialysis were individualized and aimed at correcting fluid, electrolyte, acid-base and metabolic disturbances. Intermittent Hemodialysis (IHD) and Sustained Low Efficiency Dialysis (SLED) were performed with the Fresenius $4008 \mathrm{~S}$ machine (Fresenius Medical Devices, Bad Hamburg, Germany). Continuous veno-venous hemodiafiltration (CVVHDF) was performed with the PRISMA system (Gambro Renal Products, Lakewood, CO). Unfractionated heparin was the only anticoagulant used; it was avoided in the presence of significant thrombocytopenia $(<100,000 / \mathrm{ml})$, hemorrhagic disturbances or recent surgery. The study protocol was approved by the hospital's ethics committee.

\section{Statistical Analysis}

Descriptive statistics were used to summarize the data. Categorical variables were expressed as percentages and continuous variables as mean \pm 
standard deviation or median and interquartile range (IQR), depending upon the shape of the distribution of frequencies (Gaussian versus non-Gaussian). Comparisons between two groups were performed using the Pearson Chi-square or Fisher's exact test for categorical variables or the Student's $t$ or MannWhitney U tests for continuous variables. We used univariable logistic regression analyses as a screening tool to perform a backward stepwise multivariable model to identify independent predictors of dialysis and death. Variables that showed an association with the outcome characterized by a $p$ value < 0.25 on univariable analyses were selected for the multivariable analysis. $P$ values $<0.05$ in the final multivariable model were considered statistically significant. Model fit was assessed with the HosmerLemeshow goodness-of-fit test; all calculations were performed using the statistical software package SPSS 17.0 for Windows (SPSS Inc. Chicago, IL).

\section{Results}

One hundred fourteen patients were followed. Mean age was 55.8 years; most $(61.0 \%)$ were older than 60 years. The vast majority had sepsis $(84.2 \%)$, needed mechanical ventilation $(88.6 \%)$ and norepinephrine infusion $(75.4 \%)$. At first consultation, $9.7 \%$ had stage $1,21.1 \%$ had stage 2 and $69.3 \%$ stage 3 AKI; oliguria was present in $62.3 \%$, and $65.8 \%$ underwent dialysis. Overall ICU mortality was $70.2 \%$; among survivors, most $(88.2 \%)$ recovered enough renal function to leave the ICU without the need for dialysis.

The median time from consultation to first dialysis was less than 24 hours and most patients $(59.2 \%)$ dialyzed on day 0 (the day of the first consultation). Urea (mean $\pm \mathrm{SD}$ ) levels at the time of the first dialysis were $169.7 \pm 63.3 \mathrm{mg} / \mathrm{dl}$. The median time spent on dialysis was 3 days (IQR 0 to 8.7 days). Anticoagulation was used in only $35.4 \%$ of the patients. In patients that used a single dialysis method, the most commonly used modalities were: IHD in $44.8 \%$ and CVVHDF in $26.8 \%$; a minority $(7.4 \%)$ of patients were treated with SLED. The remaining $21.0 \%$ of patients used a combination of the above methods. Clinical and laboratorial data stratified by dialysis are shown in Table 1.

To identify predictors of need for dialysis, we conducted logistic regression analyses. During univariable procedures, five independent variables measured at first nephrology consultation were selected to enter the multivariable model: age, noradrenaline use, oliguria, serum lactate $>2.5 \mathrm{mmol} / \mathrm{l}$ and serum urea (Table 1). As shown in Table 2, four of these remained independently associated with dialysis in the multivariable model.

Clinical and laboratorial data in survivors and non-survivors are shown in Table 3. Median serum creatinine in survivors and non-survivors was 3.95 $\mathrm{mg} / \mathrm{dl}$ (2.63-5.28) and $2.75 \mathrm{mg} / \mathrm{dl}$ (1.81-3.69), respectively $(p=0.004)$ (Figure 1 ).

Five variables were selected for the multivariate logistic regression model for mortality: lowest $\mathrm{PO}_{2} /$ $\mathrm{FIO}_{2}$, norepinephrine use, initial serum creatinine, lowest serum bicarbonate and peak lactate. As shown in Table 4, only four variables remained independently associated with mortality in the multivariable model, with an odds ratio of 0.69 for initial serum creatinine (CI 0.50 to $0.97, p=0.033$ ).

\section{Discussion}

In this prospective, single-center study of critically ill patients with AKI of chiefly septic etiology, serum creatinine levels were found to be inversely and independently associated with mortality. In this population, for each increase of $1 \mathrm{mg} / \mathrm{dl}$ in serum creatinine at initial nephrology consultation, there was a $31 \%$ decrease in the odds of death.

Other authors have described similar findings. Cole et al. ${ }^{5}$ found lower pre-hospital, entry and peak ICU creatinine levels in non-survivors of AKI, although this association was non-significant. Metha et al. ${ }^{2}$ identified low creatinine and high BUN as risk factors for mortality in AKI patients, but their data comes from a multicenter cohort with low percentage of septic patients. ${ }^{9}$ Also, a large multicenter cohort recently published ${ }^{19}$ identified the number of vasopressor medications, higher serum BUN and lower serum creatinine as predictors of mortality; however, the percent of septic AKI is not stated. Herein, we demonstrated this finding in a population of mainly sepsis-induced AKI diagnosed by AKIN criteria.

Since it is not plausible that lower creatinine levels increase mortality directly, this relationship is likely mediated by intervening variables (Figure 2). For example, Macedo et al. ${ }^{20}$ proposed that increases in total body water alter the volume of distribution of creatinine, resulting in artificially lower levels. 
Table 1 Clinical AND LABORATORIAL dATA IN 114 AKI PATIENTS StRATIFIED by DIALYSIS

\begin{tabular}{|c|c|c|c|c|}
\hline \multirow[b]{2}{*}{ Variables } & \multirow[b]{2}{*}{$\begin{array}{l}\text { All patients } \\
\quad(n=114)\end{array}$} & \multicolumn{2}{|c|}{ Dialysis } & \multirow[b]{2}{*}{$p^{*}$} \\
\hline & & $\begin{array}{c}\text { Yes } \\
(\mathrm{n}=80)\end{array}$ & $\begin{array}{c}\text { No } \\
(n=34)\end{array}$ & \\
\hline Age (years) ${ }^{* *}$ & $\begin{array}{c}60.0 \\
(39.2-74.0)\end{array}$ & $\begin{array}{c}56.0 \\
(33.0-73.0)\end{array}$ & $\begin{array}{c}65.0 \\
(45.00-75.0)\end{array}$ & 0.045 \\
\hline Norepinephrine use & $75.4 \%$ & $26.7 \%$ & $51.3 \%$ & 0.102 \\
\hline Oliguria & $62.3 \%$ & $69.3 \%$ & $48.7 \%$ & 0.033 \\
\hline Serum lactate $>2,5 \mathrm{mmol} / \mathrm{l}$ & $36.3 \%$ & $29.3 \%$ & $50.0 \%$ & 0.033 \\
\hline $\begin{array}{l}\text { Initial serum creatinine }{ }^{* *} \\
(\mathrm{mg} / \mathrm{dl})\end{array}$ & $\begin{array}{c}2.9 \\
(2.1-4.6)\end{array}$ & $\begin{array}{c}3.7 \\
(2.6-5.1)\end{array}$ & $\begin{array}{c}2.2 \\
(1.8-2.7)\end{array}$ & $<0.000$ \\
\hline $\begin{array}{l}\text { Initial serum urea** } \\
(\mathrm{mg} / \mathrm{dl})\end{array}$ & $\begin{array}{c}117.5 \\
(86.2-165.5)\end{array}$ & $\begin{array}{c}139.0 \\
(104.0-189)\end{array}$ & $\begin{array}{c}89.0 \\
(65.2-115.7)\end{array}$ & $<0.000$ \\
\hline $\begin{array}{l}\text { Initial serum potassium** } \\
(\mathrm{mEq} / \mathrm{l})\end{array}$ & $\begin{array}{c}4.4 \\
(3.6-5.1)\end{array}$ & $\begin{array}{c}4.4 \\
(3.4-5.1)\end{array}$ & $\begin{array}{c}4.4 \\
(3.7-5.3)\end{array}$ & 0.992 \\
\hline AKIN 3 at first consultation & $69.3 \%$ & $80.0 \%$ & $48.7 \%$ & $<0.000$ \\
\hline Serum bicarbonate $(\mathrm{mg} / \mathrm{dl})^{* *}$ & $\begin{array}{c}17.3 \\
(13.9-20.0)\end{array}$ & $\begin{array}{c}17.3 \\
(13.6-20.1)\end{array}$ & $\begin{array}{c}17.3 \\
(14.3-19.9)\end{array}$ & 0.610 \\
\hline Initial $\mathrm{PO}_{2} / \mathrm{FIO}_{2}^{* *}$ & $\begin{array}{c}270.0 \\
(167.0-367.00)\end{array}$ & $\begin{array}{c}288.0 \\
(182.0-403.0)\end{array}$ & $\begin{array}{c}230.5 \\
(135.5-336.7)\end{array}$ & 0.205 \\
\hline
\end{tabular}

* Comparisons between dialysis status; ** Data are presented as median and interquartile range (P25\%-P75\%).

\begin{tabular}{|c|c|c|c|c|}
\hline TABle 2 & \multicolumn{4}{|c|}{$\begin{array}{l}\text { MULTIVARIATE LOGISTIC REGRESSION ANALYSIS } \\
\text { FOR PREDICTORS OF DIALYSIS }\end{array}$} \\
\hline \multirow[t]{2}{*}{ Variables } & \multirow[t]{2}{*}{ OR } & \multicolumn{2}{|c|}{$\begin{array}{l}\text { 95\% Confidence } \\
\text { Interval }\end{array}$} & \multirow[t]{2}{*}{$p$} \\
\hline & & Lower & Upper & \\
\hline $\begin{array}{l}\text { Serum urea } \\
\text { (continuous) }\end{array}$ & 1.02 & 1.01 & 1.035 & $<0.000$ \\
\hline Oliguria (yes/no) & 2.99 & 1.05 & 8.48 & 0.039 \\
\hline Age (continuous) & 0.97 & 0.94 & 0.99 & 0.031 \\
\hline $\begin{array}{l}\text { Noradrenaline } \\
\text { use (yes/no) }\end{array}$ & 0.21 & 0.07 & 0.62 & 0.005 \\
\hline
\end{tabular}

Method: Backward Logistic Regression. Model fit: overall correct classification 77.7\%; Hosmer and Lemeshow Goodness of Fit test 0.415; Nagelkerke $R^{2}$ 0.421; no outliers found.

Although early, goal-directed fluid resuscitation is considered essential in sepsis treatment, ${ }^{21}$ excessive fluid administration has been linked to higher mortality in septic AKI, as well as to lower serum creatinine at AKI diagnosis. ${ }^{20,22,23}$ A lower creatinine might result, consequently, in late recognition and underestimation of AKI severity. This could delay not only consultation, which in itself has been linked to increased ICU mortality, ${ }^{24}$ but also dialysis treatment. Our data may help explain, likewise, why general severity scores that assign higher risks to higher serum creatinine levels have been found to underestimate mortality in AKI patients. ${ }^{25-28}$
Serum creatinine is also a marker for muscle mass and nutritional status. In a large multinational prospective cohort of maintenance hemodialysis patients, there was higher mortality among those with lower serum creatinine and albumin levels. ${ }^{15}$ While nutritional markers like albumin, cholesterol and nitrogen balance have recently been inversely associated to mortality ${ }^{29}$ in the AKI population, the role of serum creatinine has not been consolidated in septic AKI.

Recently, Wilson et al. ${ }^{30}$ showed a lower creatinine generation rate (CGR) in critically ill patients with AKI than what would be predicted from existing equations, and an independent association between lower CGR and mortality. However, as this author did not detail nutritional data, it was not possible to determine the causative factors of their findings.

This work has several limitations. It is a single center study involving a relatively small number of patients. Since we only included patients for whom a nephrology consult was requested, less severe AKI patients, with spontaneous recovery, may be underrepresented. Likewise, as we did not record fluid balance or evaluated nutritional status, we can only speculate that these conditions may have been responsible for our findings. 
TABLE 3 CLINICAL AND LABORATORIAL DATA OF CRITICALLY ILL AKI PATIENTS ACCORDING TO OUTCOME

\begin{tabular}{|c|c|c|c|c|}
\hline \multirow[b]{2}{*}{ Variables } & \multirow[b]{2}{*}{$\begin{array}{l}\text { All patients } \\
\quad(n=114)\end{array}$} & \multicolumn{2}{|c|}{ Outcome } & \multirow[b]{2}{*}{$p^{*}$} \\
\hline & & $\begin{array}{l}\text { Non-survivors } \\
\quad(n=75)\end{array}$ & $\begin{array}{l}\text { Survivors } \\
(\mathrm{n}=39)\end{array}$ & \\
\hline Age (years) ${ }^{* *}$ & $\begin{array}{c}60.0 \\
(39.2-74.0)\end{array}$ & $\begin{array}{c}61.0 \\
(45.5-76.5)\end{array}$ & $\begin{array}{c}42.0 \\
(23.5-60.5)\end{array}$ & 0.010 \\
\hline Norepinephrine use & $75.4 \%$ & $87.5 \%$ & $47.0 \%$ & $<0.001$ \\
\hline Oliguria & $62.3 \%$ & $67.5 \%$ & $50.0 \%$ & 0.080 \\
\hline $\begin{array}{l}\text { Initial serum creatinine } \\
(\mathrm{mg} / \mathrm{dl})^{* *}\end{array}$ & $\begin{array}{c}2.9 \\
(2.1-4.6)\end{array}$ & $\begin{array}{c}2.7 \\
(1.9-3.7)\end{array}$ & $\begin{array}{c}3.9 \\
(2.6-5.2)\end{array}$ & 0.006 \\
\hline Initial serum urea $(\mathrm{mg} / \mathrm{dl})^{* *}$ & $\begin{array}{c}117.5 \\
(86.2-165.5)\end{array}$ & $\begin{array}{c}116.0 \\
(84.0-157.0)\end{array}$ & $\begin{array}{c}126.0 \\
(88.5-188.2)\end{array}$ & 0,093 \\
\hline $\begin{array}{l}\text { Highest serum lactate } \\
(\mathrm{mEq} /)^{* *}\end{array}$ & $\begin{array}{c}3.6 \\
(2.1-5.0)\end{array}$ & $\begin{array}{c}4.2 \\
(2.3-6.0)\end{array}$ & $\begin{array}{c}1.9 \\
(1.0-2.7)\end{array}$ & $<0.001$ \\
\hline AKIN 3 at first consultation & $69.3 \%$ & $68.7 \%$ & $70.5 \%$ & 0.301 \\
\hline Lowest bicarbonate $(\mathrm{mg} / \mathrm{dl})^{* *}$ & $\begin{array}{c}15.2 \\
(12.9-18.0)\end{array}$ & $\begin{array}{c}14.0 \\
(12.2-16.7)\end{array}$ & $\begin{array}{c}17.7 \\
(14.3-19.6)\end{array}$ & 0.001 \\
\hline Lowest $\mathrm{PO}_{2} / \mathrm{FlO}_{2}{ }^{* *}$ & $\begin{array}{c}192.0 \\
(125.0-272.5)\end{array}$ & $\begin{array}{c}164.0 \\
(113.9-242.2)\end{array}$ & $\begin{array}{c}296.3 \\
(196.0-180.0)\end{array}$ & $<0.001$ \\
\hline
\end{tabular}

Figure 1. Initial serum creatinine levels in AKI patients according to outcome.

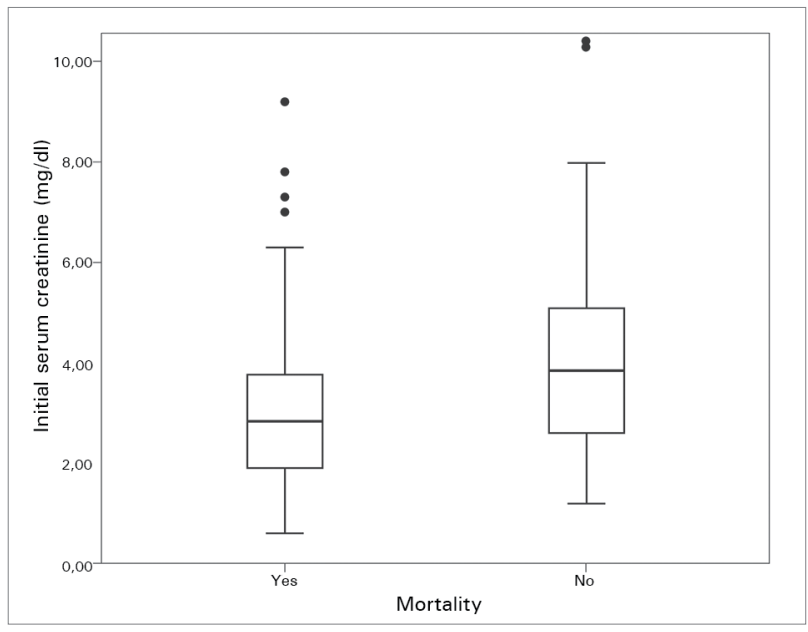

\begin{tabular}{|c|c|c|c|c|}
\hline TABLe 4 & \multicolumn{4}{|c|}{$\begin{array}{l}\text { MULTIVARIATE LOGISTIC REGRESSION ANALYSIS } \\
\text { FOR PREDICTORS OF DEATH }\end{array}$} \\
\hline \multirow[t]{2}{*}{ Variables } & \multirow[t]{2}{*}{ OR } & \multicolumn{2}{|c|}{$\begin{array}{l}\text { 95\% Confidence } \\
\text { Interval }\end{array}$} & \multirow[t]{2}{*}{$p$} \\
\hline & & Lower & Upper & \\
\hline $\begin{array}{l}\text { Initial serum } \\
\text { creatinine }\end{array}$ & 0.69 & 0.50 & 0.97 & 0.033 \\
\hline $\begin{array}{l}\text { Lowest serum } \\
\text { bicarbonate }\end{array}$ & 0.80 & 0.67 & 0.96 & 0.020 \\
\hline Peak serum lactate & 2.06 & 1.28 & 3.29 & 0.003 \\
\hline $\begin{array}{l}\text { Lowest } \mathrm{PO}_{2} / \mathrm{FIO}_{2} \\
\text { ratio }\end{array}$ & 0.99 & 0.98 & 0.99 & 0.023 \\
\hline
\end{tabular}

Method: Backward Logistic Regression. Variables removed from the equation: Norepinephrine use. Model fit: overall correct classification 84.2\%; Hosmer and Lemeshow Goodness of Fit test 0.873; Nagelkerke $R^{2} 0.585$.
Figure 2. Proposed model to explain the association between lower serum creatinine and mortality.

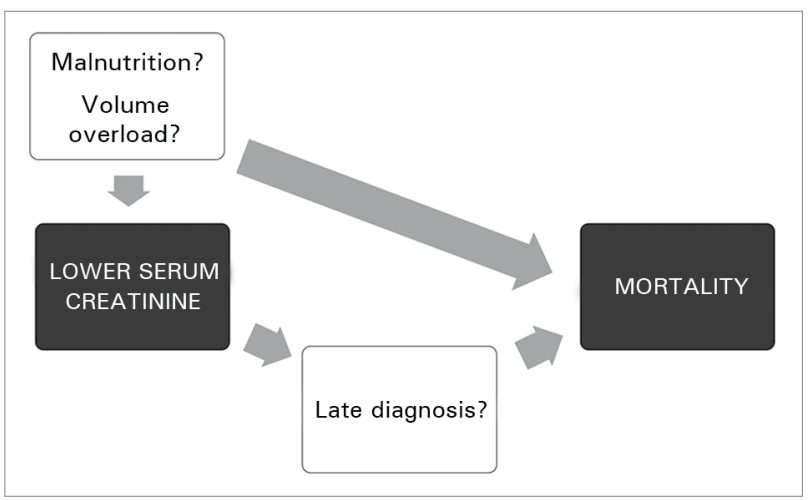

\section{Conclusions}

Although the risk factors for developing AKI have been extensively discussed in the literature, the predictors of mortality in patients who have already developed the syndrome, mainly in septic AKI, are not well known. Our finding that low creatinine is a risk factor for mortality, therefore, reinforces the suggestion that other factors linked to sepsis (malnutrition, fluid overload) or late consultation could directly influence the higher mortality in this group of patients. In view of the limitations of serum creatinine in septic AKI, the need for new biomarkers for diagnosing and staging this syndrome are urgently needed. Advances in this field could also result in more appropriate predictive scores for evaluating the risk of mortality in critical care AKI patients. 


\section{References}

1. Druml W. Prognosis of acute renal failure 19751995. Nephron 1996;73:8-15. DOI: http://dx.doi. org/10.1159/000188991

2. Mehta RL, Pascual MT, Soroko S, Savage BR, Himmelfarb J, Ikizler TA, et al.; Program to Improve Care in Acute Renal Disease. Spectrum of acute renal failure in the intensive care unit: the PICARD experience. Kidney Int 2004;66:1613-21. PMID: 15458458 DOI: http://dx.doi.org/10.1111/j.15231755.2004.00927.x

3. Liaño F, Junco E, Pascual J, Madero R, Verde E. The spectrum of acute renal failure in the intensive care unit compared with that seen in other settings. The Madrid Acute Renal Failure Study Group. Kidney Int Suppl 1998;66:S16-24.

4. Neveu H, Kleinknecht D, Brivet F, Loirat P, Landais P. Prognostic factors in acute renal failure due to sepsis. Results of a prospective multicentre study. The French Study Group on Acute Renal Failure. Nephrol Dial Transplant 1996;11:293-9. DOI: http://dx.doi.org/10.1093/oxfordjournals.ndt.a027256

5. Cole L, Bellomo R, Silvester W, Reeves JH. A prospective, multicenter study of the epidemiology, management, and outcome of severe acute renal failure in a "closed" ICU system. Am J Respir Crit Care Med 2000;162:191-6.

6. Uchino S, Kellum JA, Bellomo R, Doig GS, Morimatsu H, Morgera S, et al.; Beginning and Ending Supportive Therapy for the Kidney (BEST Kidney) Investigators. Acute renal failure in critically ill patients: a multinational, multicenter study. JAMA 2005;17:294:813-8. DOI: http://dx.doi.org/10.1001/ jama.294.7.813

7. Singbartl K, Kellum JA. AKI in the ICU: definition, epidemiology, risk stratification, and outcomes. Kidney Int 2012;81:81925. PMID: 21975865 DOI: http://dx.doi.org/10.1038/ ki.2011.339

8. Chertow GM, Soroko SH, Paganini EP, Cho KC, Himmelfarb J, Ikizler TA, et al. Mortality after acute renal failure: models for prognostic stratification and risk adjustment. Kidney Int 2006;70:1120-6. PMID: 16850028 DOI: http://dx.doi. org/10.1038/sj.ki.5001579

9. Mehta RL, Pascual MT, Gruta CG, Zhuang S, Chertow GM. Refining predictive models in critically ill patients with acute renal failure. J Am Soc Nephrol 2002;13:1350-7. DOI: http:// dx.doi.org/10.1097/01.ASN.0000014692.19351.52

10. Chen YC, Tsai MH, Hsu CW, Ho YP, Lien JM, Chang MY, et al. Role of serum creatinine and prognostic scoring systems in assessing hospital mortality in critically ill cirrhotic patients with upper gastrointestinal bleeding. J Nephrol 2003;16:558-65.

11. Paganini EP, Halstenberg WK, Goormastic M. Risk modeling in acute renal failure requiring dialysis: the introduction of a new model. Clin Nephrol 1996;46:206-11.

12. Mehta RL, Kellum JA, Shah SV, Molitoris BA, Ronco C, Warnock DG, et al.; Acute Kidney Injury Network. Acute Kidney Injury Network: report of an initiative to improve outcomes in acute kidney injury. Crit Care 2007;11:R31. DOI: http:// dx.doi.org/10.1186/cc5713

13. Gaião S, Cruz DN. Baseline creatinine to define acute kidney injury: is there any consensus? Nephrol Dial Transplant 2010;25:3812-4.

14. Chertow GM, Burdick E, Honour M, Bonventre JV, Bates DW. Acute kidney injury, mortality, length of stay, and costs in hospitalized patients. J Am Soc Nephrol 2005;16:3365-70. DOI: http://dx.doi.org/10.1681/ASN.2004090740

15. Lopes AA, Bragg-Gresham JL, Elder SJ, Ginsberg N, Goodkin $\mathrm{DA}$, Pifer T, et al. Independent and joint associations of nutritional status indicators with mortality risk among chronic hemodialysis patients in the Dialysis Outcomes and Practice Patterns Study (DOPPS). J Ren Nutr 2010;20:224-34. DOI: http://dx.doi.org/10.1053/j.jrn.2009.10.002
16. Levey AS, Coresh J, Balk E, Kausz AT, Levin A, Steffes MW, et al.; National Kidney Foundation. National Kidney Foundation practice guidelines for chronic kidney disease: evaluation, classification, and stratification. Ann Intern Med 2003;139:137-47. PMID: 12859163 DOI: http://dx.doi. org/10.7326/0003-4819-139-2-200307150-00013

17. Bellomo R, Ronco C, Kellum JA, Mehta RL, Palevsky P; Acute Dialysis Quality Initiative workgroup. Acute renal failure - definition, outcome measures, animal models, fluid therapy and information technology needs: the Second International Consensus Conference of the Acute Dialysis Quality Initiative (ADQI) Group. Crit Care 2004;8:R204-12.

18. Dellinger RP, Levy MM, Carlet JM, Bion J, Parker MM, Jaeschke R, et al.; International Surviving Sepsis Campaign Guidelines Committee; American Association of CriticalCare Nurses; American College of Chest Physicians; American College of Emergency Physicians; Canadian Critical Care Society; European Society of Clinical Microbiology and Infectious Diseases; European Society of Intensive Care Medicine; European Respiratory Society; International Sepsis Forum; Japanese Association for Acute Medicine; Japanese Society of Intensive Care Medicine; Society of Critical Care Medicine; Society of Hospital Medicine; Surgical Infection Society; World Federation of Societies of Intensive and Critical Care Medicine. Surviving Sepsis Campaign: international guidelines for management of severe sepsis and septic shock: 2008. Crit Care Med 2008;36:296-327. DOI: http://dx.doi.org/10.1097/01. CCM.0000298158.12101.41

19. Wilson FP, Yang W, Feldman HI. Predictors of death and dialysis in severe AKI: the UPHS-AKI cohort. Clin J Am Soc Nephrol 2013;8:527-37. DOI: http://dx.doi.org/10.2215/ CJN.06450612

20. Macedo E, Bouchard J, Soroko SH, Chertow GM, Himmelfarb J, Ikizler TA, et al.; Program to Improve Care in Acute Renal Disease Study. Fluid accumulation, recognition and staging of acute kidney injury in critically-ill patients. Crit Care 2010;14:R82.

21. Angus DC. Management of sepsis: a 47-year-old woman with an indwelling intravenous catheter and sepsis. JAMA 2011;305:1469-77. PMID: 21467273 DOI: http://dx.doi. org/10.1001/jama.2011.438

22. Bouchard J, Soroko SB, Chertow GM, Himmelfarb J, Ikizler TA, Paganini EP, et al. Fluid accumulation, survival and recovery of kidney function in critically ill patients with acute kidney injury. Kidney Int 2009;76:422-7. PMID: 19436332 DOI: http://dx.doi.org/10.1038/ki.2009.159

23. Payen D, de Pont AC, Sakr Y, Spies C, Reinhart K, Vincent JL; Sepsis Occurrence in Acutely Ill Patients (SOAP) Investigators. A positive fluid balance is associated with a worse outcome in patients with acute renal failure. Crit Care 2008;12:R74. DOI: http://dx.doi.org/10.1186/cc6916

24. Ponce D, Zorzenon Cde P, dos Santos NY, Balbi AL. Early nephrology consultation can have an impact on outcome of acute kidney injury patients. Nephrol Dial Transplant 2011;26:3202-6. DOI: http://dx.doi.org/10.1093/ndt/ gfr359

25. Ostermann M, Chang RW. Acute kidney injury in the intensive care unit according to RIFLE. Crit Care Med 2007;35:1837-43. DOI: http://dx.doi.org/10.1097/01. CCM.0000277041.13090.0A

26. Hoste EA, Lameire NH, Vanholder RC, Benoit DD, Decruyenaere JM, Colardyn FA. Acute renal failure in patients with sepsis in a surgical ICU: predictive factors, incidence, comorbidity, and outcome. J Am Soc Nephrol 2003;14:1022-30. DOI: http://dx.doi.org/10.1097/01. ASN.0000059863.48590.E9 
27. Gill N, Nally JV Jr, Fatica RA. Renal failure secondary to acute tubular necrosis: epidemiology, diagnosis, and management. Chest 2005;128:2847-63. PMID: 16236963 DOI: http:// dx.doi.org/10.1378/chest.128.4.2847

28. Costa e Silva VT, de Castro I, Liaño F, Muriel A, Rodríguez-Palomares JR, Yu L. Performance of the third-generation models of severity scoring systems (APACHE IV, SAPS 3 and MPM-III) in acute kidney injury critically ill patients. Nephrol Dial Transplant 2011;26:3894-901. DOI: http://dx.doi.org/10.1093/ndt/gfr201
29. Berbel MN, Pinto MP, Ponce D, Balbi AL. Nutritional aspects in acute kidney injury. Rev Assoc Med Bras 2011;57:600-6. PMID: 22012298 DOI: http://dx.doi.org/10.1590/S010442302011000500022

30. Wilson FP, Sheehan JM, Mariani LH, Berns JS. Creatinine generation is reduced in patients requiring continuous venovenous hemodialysis and independently predicts mortality. Nephrol Dial Transplant 2012;27:4088-94. DOI: http://dx.doi. org/10.1093/ndt/gfr809 